\title{
RESEARCH CONCERNING FLORISTIC COMPOSITION AND DEGREE OF WEED INFESTATION OF CEREAL CROPS IN CONSTANTA COUNTY
}

\author{
Marga Grădilă*, Daniel Jalobă, Valentin Marius Ciontu, Raluca Monica Cristea
}

Research - Development Institute for Plant Protection Bucharest, Romania

* correspondence address:

Research-Development Institute for Plant Protection

8 Ion Ionescu de la Brad 013813, Bucharest, Romania

Phone: + 40212693231

Fax: + 40212693239

e-mail: marga.gradila@icdpp.ro

http://www.doi.org/10.54574/RJPP.14.14

\begin{abstract}
Weeds mapping aims to know the segetal floristic spectrum from the point of view of the degree of weed infestation and the frequency of weeds in each crop. Cereals crops are yearly infested by dicotyledonous and monocotyledonous weeds species, annual and perennial, some of them being very harmful, difficult to control and known as dominant weeds or problem weeds. Research carried out in Constanţa county, Agigea and Runcu villages, during 2020-2021 years, was concerned with segetal flora assessment. The main purposes considered were: the study of the issues related to the floristic composition, the dynamics of the degree of weed infestation, the identification of the dominant species, the establishment of the most effective herbicide treatments and of the optimal times of application. The analysis of the obtained data reveals that the problem weeds with a density $>10$ plants $/ \mathrm{m}^{2}$ identified in the wheat and barley crops in Agigea were: Veronica species, Papaver rhoeas, Chenopodium album, Polygonum convolvulus and Fumaria officinalis. The dominant weed species in wheat and barley crops of Runcu were: C. album, Convolvulus arvensis, Stellaria media, Equisetum arvense and Cannabis ruderalis. Although the dicotyledonous species prevail in both studied places, the weed control strategy is different because the target species against which control measures must be applied are different and consequently the range of herbicides will also be different. The results obtained fully justify the weed mapping action because it is a tool that offers the farmer the exact perception regarding the degree of weed infestation in the studied areas. Mapping thus becomes a very useful work for weed control practice.
\end{abstract}

Keywords: mapping, cereals, weeds, degree of weed infestation

\section{INTRODUCTION}

Weed infestation is one of the major biotic constraints in cereal production. Even if many weed species have adapted itself to environmental conditions, the ever - changing agricultural habitats selectively disturb the weed communities and thus modify the segetal flora (Rademacher et al., 1970; Reuss, 1981; Mahn, 1984; Chancellor, 1985; Légére et al., 1993). As cereals are grown all over the country under contrasting pedoclimatic conditions, the segetal flora that infests these crops is varied both in species and in the degree of weed infestation, but especially as a relationship between species. On the whole, cereal grains can compete with weeds because they cover the soil very well and do not allow their development, but dangerous invasions can occur in early autumn or spring, it means before the soil is covered by plants. Biennial or perennial weed species are just as deleterious because they have a better growth rate than cereals. At the same time, some species, such as cleavers Galium aparine (L.), small bindweed Convolvulus arvensis (L.), creeping thistle Cirsium arvense (L.) Scop. are harmful not so much by competition, but by the fact that they obstruct harvesting and have a prejudicious influence on seed purity. 
As a result, the losses caused by weeds range between very wide limits depending on the species and density, the degree of weed infestation, pedoclimatic conditions and cropping technology, ranging in the absence of prevention and control measures, from 10 till $70 \%$ of potential production (Cudney \& Hill, 1979; Malik \& Singh, 1993; Khera et al., 1995; Malik \& Singh, 1995; Afentouli \& Eleftherohorionos, 1996; Mehra \& Gill, 1988; Chhokar \& Malik, 2002; Ion, 2010; Petre \& Carciu, 2013; Santín-Montanyá et al., 2013). In extreme cases, the losses caused by weeds can be up to complete crop failure (Malik et al., Singh, 1995). Weed control is the main task in cereal crops because weed competition is the biggest source of loss of yield at global level (Liebman et al., 2001). Weed mapping is the one of the important concerns for the elaboration of the complex and specific management of each crop.

Weed mapping has a decisive role in obtaining accurate data on the dynamics and control of the segetal flora at the level of each plot (Berca, 1995 and 2004; Chirilă, 1988; Slonovski \& Lăzărescu, 2000; Slonovski et al., 2001). For a better knowledge of the degree of weeding in a farm, the mapping action can be repeated at appropriate times, knowing that in the evolution of weeds there is a certain dynamic of adaptation-readaptation to the agricultural system used. Weed mapping thus becomes a very useful action for weed control practice. By its help it is possible to forecast, in time, the emergence of weeds.

In this context, the research carried out in the villages of Agigea and Runcu from Constanța County during 2020-2021 in autumn wheat and barley crops aimed at mapping the segetal flora. The main objectives considered were: the study of the aspects related to the floristic composition, the dynamics of the degree of weed infestation, the recognition of the dominant species, the establishment of the most effective herbicide treatments and of the optimal times of application.

\section{MATERIALS AND METHODS}

Research was conducted in wheat and barley crop in Agigea and Runcu villages, Constanța County, during 2020 - 2021 (Figures 1 and 2).

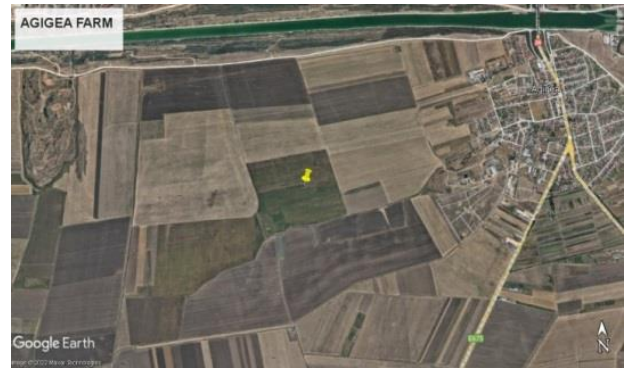

Figure 1. Location of Agigea farm

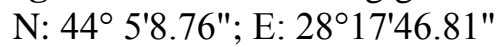

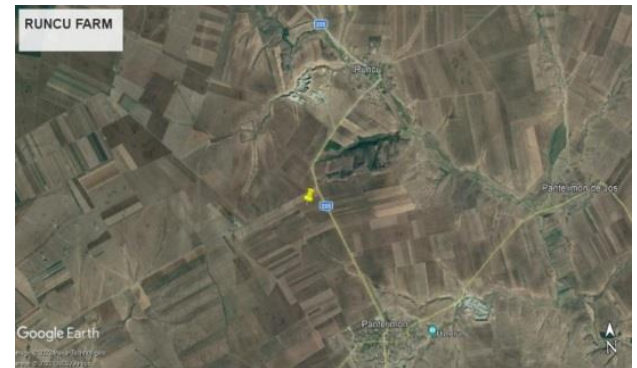

Figure 2. Location of Runcu farm N: 4434'22.39"; E: 28³3'43.45"

Weed mapping was conducted in 10 fields sown with winter wheat and 10 with winter barley, included in a suitable crop rotation. The numerical method of weeds assessments was used to which the phenophase and the average height of each plant were added. There were 50 samples taken for each 1 hectare surface. The cereal crops in which the assessments were performed, were cultivated by private farmers according to their own technologies.

For each field, landfills of weed infestation have been done and they present both general data on the location, the soil type, the previous crop and specific data on the density, participation and constancy of each weed species, class (monocotyledonous or dicotyledonous) as well the life period of each weed (ephemeral, annual, biennial, or 
perennial). For sampling and weeds inventory, the metric frame $\left(1 \mathrm{~m}^{2}\right)$ was used. Each sampling point was established by going through the field in 1-2 diagonals according to the number of specified samples. At the final stage, the data obtained from all the analysed samples were centralised.

The data obtained on weed infestation of cereal crops cultivated in rotation system reveals the ecological characteristics of the weed flora existing at a certain moment in the studied fields. Finally, the weeds were distributed in density categories in descending order to identify the dominant species and the problem weeds, the results obtained by mapping being an important tool in taking the most appropriate weed control measures in a crop.

\section{RESULTS AND DISCUSSIONS}

Wheat and barley crops sown in the assessed areas are yearly weed-infested with segetal species belonging to diverse, annual, biennial and perennial botanical families, some of them very difficult to fight against. Thus, at Agigea, 33 weed species with an average density of 172 plants $/ \mathrm{m}^{2}$ were identified (Table 1). Analysing the data in Table 1, we can see that the most important weed species belong to the annual dicotyledonous.

Table 1. Weed mapping in wheat and barley crops of Agigea

\begin{tabular}{|c|c|c|c|c|c|c|c|}
\hline \multicolumn{8}{|c|}{$\begin{array}{l}\text { Wheat and Barley, Agigea, Constanța, Farmer Lamureanu Gheorghe } \\
\text { Years 2020-2021; Soil: vermi-calcium chernozem; Previous crop: Maize }\end{array}$} \\
\hline No. & Species & $\begin{array}{l}\text { Stage/height } \\
(\mathrm{cm})\end{array}$ & $\begin{array}{l}\text { Average } \\
\text { no. } / \mathrm{m}^{2}\end{array}$ & $\begin{array}{l}\mathrm{P} \\
(\%)\end{array}$ & $\begin{array}{c}\mathrm{K} \\
(\%)\end{array}$ & Family & $\begin{array}{c}\text { Life } \\
\text { period }\end{array}$ \\
\hline \multicolumn{8}{|c|}{ Weeds with density: $>10$ plants $/ \mathrm{m}^{2}$} \\
\hline 1. & Veronica species & A-B-C; 6-10 & 20.6 & 11.9 & 100 & Plantaginaceae & AIDW \\
\hline 2. & Papaver rhoeas & $\mathrm{A} ; 10-25$ & 14.0 & 8.1 & 100 & Papaveraceae & $\mathrm{AD}$ \\
\hline 3. & Chenopodium album & $\mathrm{A} ; 10-25$ & 13.6 & 7.9 & 100 & Amaranthaceae & $\mathrm{AD}$ \\
\hline 4. & Polygonum convolvulus & $\mathrm{A} ; 10-25-30$ & 12.0 & 7.0 & 100 & Polygonaceae & $\mathrm{AD}$ \\
\hline 5. & Fumaria officinalis & $\mathrm{A} ; 10-25-30$ & 10.8 & 6.3 & 80 & Papaveraceae & $\mathrm{AD}$ \\
\hline \multicolumn{8}{|c|}{ Weeds with density: $>5$ plants $/ \mathrm{m}^{2}$} \\
\hline 6. & Galium aparine & A-B; 20-25 & 10.0 & 4.6 & 76.0 & Rubiaceae & $\mathrm{AD}$ \\
\hline 7. & Echinochloa crus-galli & A; $3-15-20$ & 8.0 & 4.6 & 80.0 & Poaceae & AM \\
\hline 8. & Sinapis arvensis & $\mathrm{A} ; 15$ & 6.2 & 3.6 & 60.0 & Brasicaceae & ADW \\
\hline 9. & Daucus carota & $\mathrm{A} ; 12$ & 6.2 & 3.6 & 56.0 & Apiaceae & $\mathrm{ABD}$ \\
\hline 10. & Sonchus oleraceus & $\mathrm{A} ; 10-18$ & 6.0 & 3.4 & 50.0 & Asteraceae & $\mathrm{AD}$ \\
\hline 11. & Capsella bursa-pastoris & $\mathrm{A} ; 10$ & 5.5 & 3.2 & 50.0 & Brasicaceae & ADW \\
\hline 12. & Lamium amplexicaule & A-B; $15-20$ & 5.4 & 3.1 & 48.0 & Lamiaceae & ADW \\
\hline 13. & Cardaria draba & $\mathrm{A} ; 20$ & 5.2 & 3.0 & 44.0 & Brasicaceae & PD \\
\hline 14. & Stellaria media & $\mathrm{A} ; 10-15$ & 5.2 & 3.0 & 44.0 & Caryophyllaceae & ABDW \\
\hline \multicolumn{8}{|c|}{ Weeds with density: $>2$ plants $/ \mathrm{m}^{2}$} \\
\hline 15. & Setaria species & $\mathrm{A} ; 8-20$ & 5.0 & 2.9 & 48.0 & Poaceae & AM \\
\hline 16. & Descurainia sophia & $\mathrm{A} ; 15-20$ & 3.8 & 2.2 & 32.0 & Brasicaceae & $\mathrm{AD}$ \\
\hline 17. & Cirsium arvense & $\mathrm{A} ; 12$ & 3.6 & 2.0 & 30.0 & Asteraceae & PD \\
\hline 18. & Ranunculus arvensis & A-C; 20-25 & 3.2 & 1.8 & 24.0 & Ranunculaceae & $\mathrm{AD}$ \\
\hline 19. & Erigeron annuus & $\mathrm{A} ; 15-20$ & 3.0 & 1.7 & 20.0 & Asteraceae & AID \\
\hline 20. & Convolvulus arvensis & A-B; $10-15-25$ & 3.0 & 1.7 & 24.0 & Convolvulaceae & $\mathrm{PD}$ \\
\hline 21. & Ambrosia artemisiifolia & $\mathrm{A} ; 10-15$ & 2.2 & 1.3 & 12.0 & Asteraceae & AID \\
\hline \multicolumn{8}{|c|}{ Weeds with density: $1-2$ plants $/ \mathrm{m}^{2}$} \\
\hline 22. & Viola arvensis & A-B-C; 6-10 & 2.0 & 1.1 & 8.0 & Violaceae & $\mathrm{AD}$ \\
\hline 23. & Amaranthus species & $\mathrm{A} ; 10-25$ & 2.0 & 1.1 & 8.0 & Amaranthaceae & $\mathrm{AD}$ \\
\hline 24. & Consolida regalis & A-C; $20-25$ & 2.0 & 1.1 & 8.0 & Ranunculaceae & $\mathrm{AD}$ \\
\hline 25. & Matricaria inodora & A-C; $20-25$ & 2.0 & 1.1 & 8.0 & Asteraceae & ABDW \\
\hline 26. & Bromus secalinus & A-B; $20-25$ & 2.0 & 1.1 & 8.0 & Poaceae & AIMW \\
\hline
\end{tabular}




\begin{tabular}{|c|c|c|c|c|c|c|c|}
\hline 27. & Lolium multiflorum & A-B; $20-25$ & 1.8 & 1.0 & 6.0 & Poaceae & ABMW \\
\hline 28. & Anagallis arvensis & $\mathrm{A} ; 10$ & 1.6 & 0.9 & 6.0 & Primulaceae & ADW \\
\hline 29. & Trifolium pratense & A; $10-15$ & 1.6 & 0.9 & 4.0 & Fabaceae & PD \\
\hline 30. & Centaurea cyanus & A-C; $10-15$ & 1.5 & 0.8 & 4.0 & Asteraceae & ADW \\
\hline 31. & Lithospermum arvense & A; $10-15$ & 1.0 & 0.5 & 2.0 & Boraginaceae & AID \\
\hline 32. & Conyza canadensis & A; $20-40$ & 1.0 & 0.5 & 2.0 & Asteraceae & APID \\
\hline 33. & Taraxacum officinale & A-C; $10-15$ & 1.0 & 0.5 & 2.0 & Asteraceae & PD \\
\hline \multicolumn{3}{|c|}{ TOTAL } & 172 & 100 & & & \\
\hline
\end{tabular}

Legend

$\mathrm{A}=5$ - 7 leaves unfolded/shoot; $\mathrm{B}=$ flower buds/Gramineous - bootstage; $\mathrm{C}=$ Flowering.

$\mathrm{P} \%=$ Proportion in which each species was involved to general weed infestation.

$\mathrm{K} \%=$ Proportion in which each species was found in observation points.

$\mathrm{PM}=$ perennial monocotyledonous; $\mathrm{AM}=$ annual monocotyledonous.

$\mathrm{PD}=$ perennial dicotyledonous; $\mathrm{AD}=$ annual dicotyledonous; $\mathrm{I}=$ invasive species .

$\mathrm{ABD}=$ annual or biannual dicotyledonous.

ADW = annual or winter annual dicotyledonous.

$\mathrm{ABDW}=$ annual, biennial, winter or perennial dicotyledonous.

ABMW = annual, biennial, winter or perennial monocotyledonous.

These species are usually dominant and are important because they cause important losses in crops. From a practical point of view, these species have been called problem-weeds (Turk \& Tawaha, 2003; Sarangi \& Jhala, 2018; Gibson et al., 2005; Khan et al., 2011).

Among the problem weeds, some are considered target species, according to which specific weed control decisions are taken in a crop (Ionescu et al., 2016).

In order for the farmers to know the problem weeds against effective control measures must be applied, the 33 weed species were divided into 4 categories according to their density. Thus in the first category with a density $>10$ plants $/ \mathrm{m}^{2}$ included the species: Veronica $\mathrm{spp}$., Papaver rhoeas (L.), Chenopodium album (L.), Polygonum convolvulus (L.) and Fumaria officinalis (L.). The species with the highest density $\left(>20\right.$ plants $\left./ \mathrm{m}^{2}\right)$ were represented by plants of the genus Veronica. In the spontaneous Romanian flora, the genus Veronica is represented by 41 species and 3 hybrids grouped in 5 subgenera (Săvulescu et al., 1960). Of the various species of veronica, we have identified 4 species: Veronica officinalis, V. persica, $V$. hederifolia and $V$. arvensis.

The second category had a density $>5 \mathrm{plants} / \mathrm{m}^{2}$ and there were found the following species: Galium aparine (L.), Echinochloa crus-galli (L.) Pal. Beauv, Sinapis arvensis (L.), Daucus carota (L.), Sonchus oleracus (L.), Capsella bursa-pastoris (L.) Medic., Lamium amplexicaule (L.), Cardaria draba (L.) Desv., and Stellaria media (L.) Vill.

The third category including 7 species with a density $>2$ plants $/ \mathrm{m}^{2}$ (Table 1$)$. Although these species, due to their density, are not a problem for wheat and barley crops from Agigea, some of them are difficult to control, being perennial Convolvulus arvensis (L.), others are prolific Setaria species and others invasive Ambrosia artemisiifolia (L.) and Bromus secalinus (L.). The dynamics of these species must be followed on particular consideration because at any time they can become problem weeds and they may cause the reducing of the yields both quantitatively and qualitatively. The last category was the most numerous including 12 species with a low density (1-2 plants $\left./ \mathrm{m}^{2}\right)$. However, the presence of perennial species is noticeable (Trifolium pratense and Taraxacum officinale).

The distribution of weed species by botanical groups according to density and the percentage of participation of each species in wheat and barley crops from Agigea is presented in figure 3. Analyzing the database, it is obvious that the problem weeds are represented by the annual dicotyledonous species, which included 24 species with a density of 
140.8 plants $/ \mathrm{m}^{2}$ and a participation rate of $81 \%$ in the general weed infestation of cereal crops in Agigea.

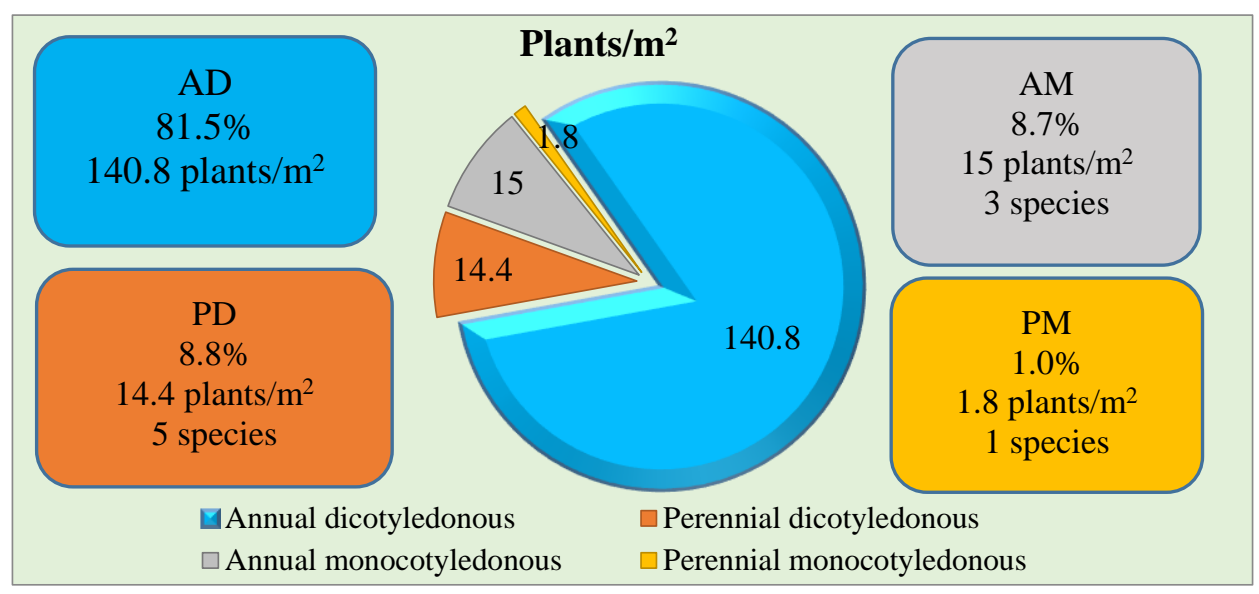

Figure 3. Distribution of weed species by botanical groups - Agigea (Constanța)

In the wheat and barley crops from Runcu there were recorded 20 weed species with a mean density of 125 plants $/ \mathrm{m}^{2}$. The first category with a density higher than 10 plants $/ \mathrm{m}^{2}$ also included dicotyledonous weed species: $C$. album, C. arvensis, S. media, Equisetum arvense (L.) and Cannabis ruderalis (Janisch.). The second category had a density $>5$ plants $/ \mathrm{m}^{2}$, being found the following species: P. convolvulus, Setaria spp., Brassica napus (L.), Veronica species and Papaver rhoeas (table 2).

Table 2. Weed mapping in wheat and barley crops of Runcu

\begin{tabular}{|c|c|c|c|c|c|c|c|}
\hline \multicolumn{8}{|c|}{$\begin{array}{l}\text { Wheat and Barley, Agigea, Constanța, Farmer Altan Abduraman } \\
\text { Years 2020-2021; Soil: Cambic chernozem; Previous crop: Sunflower }\end{array}$} \\
\hline No. & Species & Stage/ height $(\mathrm{cm})$ & $\begin{array}{l}\text { Average } \\
\text { no. } / \mathrm{m}^{2}\end{array}$ & $\begin{array}{c}\mathrm{P} \\
(\%)\end{array}$ & \begin{tabular}{c|c}
$\mathrm{K}$ \\
$(\%)$
\end{tabular} & Family & $\begin{array}{c}\text { Life } \\
\text { period }\end{array}$ \\
\hline \multicolumn{8}{|c|}{ Weeds with density: $>10$ plants $/ \mathrm{m}^{2}$} \\
\hline 1. & Chenopodium album & $\mathrm{A} ; 12-25$ & 15.5 & 12.4 & 100 & Amaranthaceae & $\mathrm{AD}$ \\
\hline 2. & Convolvulus arvensis & A-B; $15-25$ & 12.4 & 9.6 & 100 & Convolvulaceae & $\mathrm{AD}$ \\
\hline 3. & Stellaria media & $\mathrm{A} ; 6-12$ & 11.0 & 8.8 & 100 & Caryophyllaceae & ABDW \\
\hline 4. & Equisetum arvense & $\mathrm{A} ; 15-20$ & 10.8 & 8.6 & 80 & Equisetidae & PID \\
\hline 5. & Canabis ruderalis & A; $12-20$ & 10.6 & 8.5 & 80 & Cannabaceae & PID \\
\hline \multicolumn{8}{|c|}{ Weeds with density: $>5$ plants $/ \mathrm{m}^{2}$} \\
\hline 6. & Polygonum convolvulus & $\mathrm{A} ; 10-20-30$ & 10.0 & 8.0 & 100 & Polygonaceae & $\mathrm{AD}$ \\
\hline 7. & Setaria species & $\mathrm{A} ; 8-20$ & 8.6 & 7.0 & 80.0 & Poaceae & $\mathrm{AM}$ \\
\hline 8. & Brassica napus & $\mathrm{A} ; 10-25$ & 7.8 & 6.2 & 60.0 & Brasicaceae & $\mathrm{ABD}$ \\
\hline 9. & Veronica species & A-B-C; 6-10 & 5.6 & 4.5 & 50.0 & Plantaginaceae & AIDW \\
\hline 10. & Papaver rhoeas & $\mathrm{A} ; 10-25$ & 5.2 & 4.2 & 50.0 & Papaveraceae & $\mathrm{AD}$ \\
\hline \multicolumn{8}{|c|}{ Weeds with density: $>2$ plants $/ \mathrm{m}^{2}$} \\
\hline 11. & Daucus carota & $\mathrm{A} ; 12$ & 4.2 & 3.4 & 48.0 & Apiaceae & $\mathrm{ABD}$ \\
\hline 12. & Fumaria officinalis & A; $10-25-30$ & 4.0 & 3.2 & 44.0 & Papaveraceae & $\mathrm{AD}$ \\
\hline 13. & Erigeron aпnииs & A; $15-20$ & 3.8 & 3.0 & 32.0 & Asteraceae & AID \\
\hline 14. & Galium aparine & A-B; $20-25$ & 3.4 & 2.8 & 20.0 & Rubiaceae & $\mathrm{AD}$ \\
\hline 15. & Echinochloa crus-galli & A; 3-1-20 & 3.0 & 2.4 & 20.0 & Poaceae & $\mathrm{AM}$ \\
\hline \multicolumn{8}{|c|}{ Weeds with density: $1-2$ plants $/ \mathrm{m}^{2}$} \\
\hline
\end{tabular}




\begin{tabular}{|c|c|c|c|c|c|c|c|}
\hline 16. & Hibiscus trionum & $\mathrm{A} ; 5-10$ & 2.0 & 1.6 & 12.0 & Malvaceae & $\mathrm{AD}$ \\
\hline 17. & Verbena officinalis & $\mathrm{A} ; 10$ & 2.0 & 1.6 & 8.0 & Verbenaceae & PD \\
\hline 18. & Sonchus oleraceus & A; $10-18$ & 1.8 & 1.5 & 6.0 & Asteraceae & $\mathrm{AD}$ \\
\hline 19. & Erigeron canadensis & A; $15-20$ & 1.8 & 1.5 & 4.0 & Asteraceae & AID \\
\hline 20. & Myosotis arvense & $\mathrm{A} ; 15$ & 1.5 & 1.2 & 2.0 & Brasicaceae & ADW \\
\hline \multicolumn{3}{|c|}{ TOTA } & 125 & 100 & & & \\
\hline
\end{tabular}

Among the weed species of the third category, with a density higher than 2 plants $/ \mathrm{m}^{2}$, it was noticed the presence of E. annuus and of the last category with a density of 1-2 plants/ $\mathrm{m}^{2}$ E. canadensis was recorded. The distribution of weed species by botanical groups according to density and the percentage of participation of each species in wheat and barley crops from Runcu is shown in figure 4. Analyzing the presented data, it is evident that the problem weeds are represented by the annual dicotyledonous species, which included 14 species with a density of 77.6 plants $/ \mathrm{m}^{2}$ and a participation percentage $>$ of $62 \%$ in the general weed infestation of cereal crops in Runcu. There is also an increase in the share of perennial dicotyledons in the general weeding of wheat and barley crops, respectively $28.3 \%$ compared to Agigea, where their share was $8.8 \%$ ( Figure 4 ).

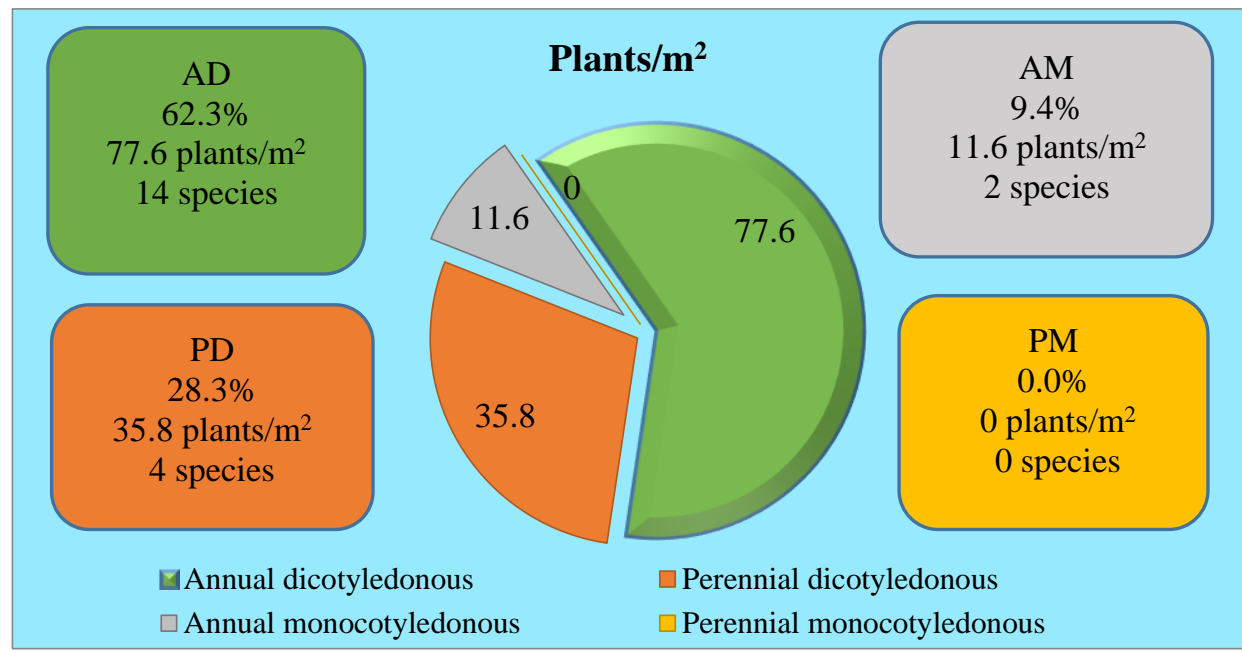

Figure 4. Distribution of weed species by botanical groups - Runcu (Constanța)

Considering the species which demand special control measures, we can see that there are 3 target species at Agigea, as follows: Veronica species, $P$. rhoeas and $P$. convolvulus. At Runcu, $C$. arvensis, E. arvense and $C$. ruderalis are the ones. Although in these 2 locations the dicotyledonous ones exceeded, weed control strategy should be different, as the target weeds supposed to be controlled are not the same and therefore another range of herbicides would be applied.

The results obtained fully justify the weed mapping task as this is an useful tool that offers the farmer the specific situation regarding the degree of weed infestation in the studied areas. Mapping thus becomes a very useful action for weed control management. In Agigea, even if perennial species grow in the area, the application of herbicides against perennial weeds is not justified (because the density is below the economic damage threshold), while in Runcu the application of such herbicides is mandatory due to the presence of perennial species $C$. arvensis. In Romania this species has a great ecological plasticity and creates special problems, generated especially by its ability to reproduce, through seeds but especially vegetative, as well as resistance to many herbicides. Aspects regarding the research carried out in the 2 experimental fields are presented in figure 5. 


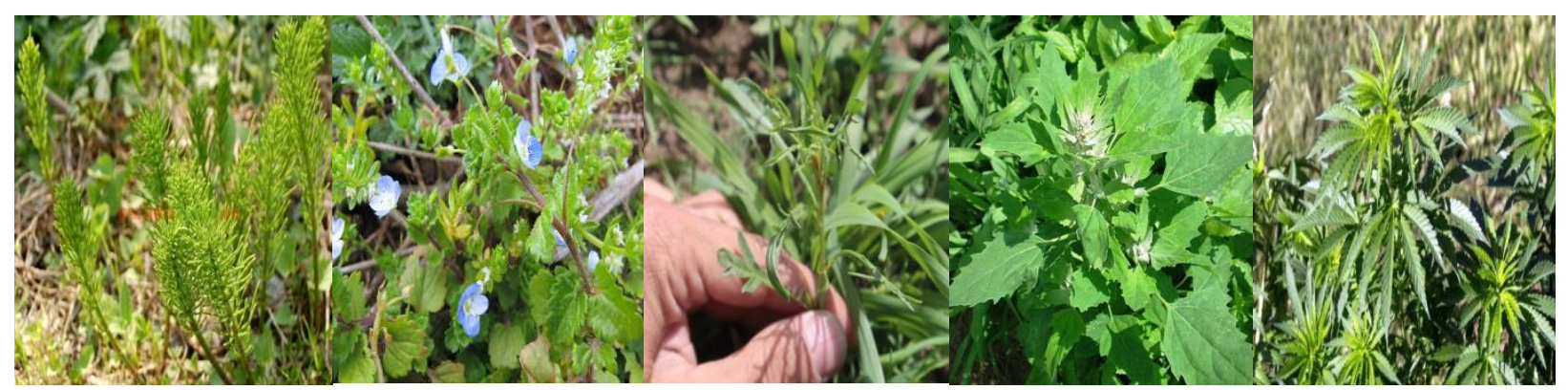

Figure 5. Aspect from experimental plots

\section{CONCLUSIONS}

Cereal crops are infested every year with dicotyledonous and monocotyledonous weed species, some of them being very deleterious, difficult to control and known as dominant weeds or problem weeds.

In the wheat and barley crops of Agigea, the problem weeds were represented by 24 annual dicotyledonous species. Their density was of 140.8 plants $/ \mathrm{m}^{2}$ and ground cover exceeded $81 \%$ within the whole weed infestation.

In wheat and barley crops of Runcu, annual dicotyledonous species were also the problem weeds including 14 species. Their density was of 77.6 plants $/ \mathrm{m}^{2}$ and frequency exceeded $62 \%$ in the whole weed infestation.

The target weeds identified at Agigea, for whom special control measures must be applied, are Veronica species and $P$. convolvulus and at Runcu $C$. arvensis, E. arvense and $C$. ruderalis.

Following this research, the farmer is in posession of all necessary data to establish the optimal weed control strategy according to problematic species and target weeds, thus weed mapping becomes a very useful practice and integrated weed management control action.

Among the invasive species identified, some are of particular importance because they reduce biodiversity, they cause a depreciation of crops both quantitatively and qualitatively, and others are harmful to human health, being allergenic, having the effect of increasing costs: V. persica, E. annuus, E. canadensis, A. artemisiifolia etc.

\section{Acknowledgement}

Special thanks to farmers who helped this study.

\section{REFERENCES}

AFENTOULI, G.C., ELEFTHEROHORINOS, I.G. (1996). Little seeded canary grass (Phalaris minor) and short-spiked canary grass (Phalaris brachystachys) interference in wheat and barley. Weed Science, 44, 560-565.

BERCA, M. (2004). Integrated weed management, Ceres Publishing House, Bucharest, 534.

BERCA, M. (1995). Combaterea buruienilor din culturile agricole. Ed. Fermierul român, București, 155-158.

CHANCELLOR, R. J. (1985). Changes in the weed flora of anarable field cultivated for 20 years. Journal of Applied Ecology, 22, 491-501.

CHHOKAR, R.S. \& MALIK, R.K. (2002). Isoproturon resistant Phalaris minor and its response to alternate herbicides. Weed Technology, 16, 116-123.

CHIRILĂ, C. (1988). Cartarea - componentă a sistemului integrat de prevenire şi combatere a buruienilor. Simpozionul Național de Herbologie, București, 6, 19-24. 
CUDNEY, D.W., HILL, J.E. (1979). The response of wheat grown with three population levels of canary grass to various herbicide treatments. Proc. West. Soc. Weed Science, 32, 55-66.

GIBSON, K. D., JOHNSON, W. G., HILLGER D. E. (2005). Farmer perceptions of problematic corn and soybean weeds in Indiana, Weed Technology, 19, 4, 1065-1070.

ION, V. (2010). Fitotehnie. Curs Universitar, Fac. Horticultură București. www. horticulturabucuresti. ro/images/pdf/Fitotehnie. pdf.

IONESCU, N., TRAȘCĂ, F., MINCĂ, G., TRAȘCĂ, G., VOICA, M., CIODARU, I., PENESCU, A. (2016). Weeds mapping from wheat and maize crops. Analele Institutului Național de CercetareDezvoltare Agricolă Fundulea, 84, 189-197.

KHAN, I., ULLAH, A., GUL, F., ALI, K. (2011). Weeds as a major constraint in wheat production in district Peshawar. Pakistan Journal of Weed Science Research, 17, 4, 381-386.

KHERA, K.L., SANDHU, B.S., AUJLA, T.S., SINGH, C.B., KUMAR, K. (1995). Performance of wheat (Triticum aestivum) in relation to small canarygrass (Phalaris minor) under different levels of irrigation, nitrogen and weed population. The Indian Journal of Agricultural Sciences, 65, 717-722.

LÉGÉRE, A., LEMIEUX, C., SIMARD, R. R., LAPIERRE, C. (1993). Response of weed community es to fertility and tillage. Proc. Bth EWRS Symp., Quantitative Approaches of Weed and Herbicide Research, 1, 41-48.

LIEBMAN, M., MOHLER, C. M., STAVER, C. P. (2001). Ecological Management of Agricultural Weeds. Cambridge University Press, Cambridge, 532. Doi: 10.1017/CBO9780511521810

MAHN, E. G. (1984). The influence of different nitrogen levels on the productivity and structural changes of weed communities in agroecosystems. Proc. $7^{\text {th }}$ Int. Symp. On Weed Biology and Systematics, Paris, 421-429.

MALIK, R. K., SINGH, S. (1993). Evolving strategies for herbicide use in wheat: Resistance and integrated weed management. International Symposium on Integrated Weed, Hisar, India, 1, 225-238.

MALIK, R.K., SINGH, S. (1995). Littleseed canarygrass (Phalaris minor Retz.) resistance to isoproturon in India. Weed Technology, 9, 419-425.

MEHRA, S.P., GILL, H.S. (1988). Effect of temperature on germination of Phalaris minor Retz. and its competition in wheat. Pakistan Journal of Agricultural Science, 25, 529 - 533.

PETRE (SULUGIU), C., CARCIU, G. (2013). Dynamics of weeding of winter wheat and grain maize in Western Caras-Severin County, Romania. Journal of Horticulture, Forestry and Biotechnology, 17, 2, 294-298.

RADEMACHER, B., KOCH, W., HURLE, K. (1970). Changes in the weed flora as the result of continuous cropping of cereal sand the annual use of the same weed control measures since. Brighton Weed Conference, 10, 1-6.

REUSS, H.U. (1981). Untersuchung des Einflussesproduk - tions technischerundökologischer Faktorenaufdiequan - titative und qualitative Veränderung derstandörtlichen Unkrautfloraauf Ackerland, Technischen Universität Munchen, 116.

SANTÍN-MONTANYÁ, I., ZAMBRANA-QUESADA, E., TENORIO-PASAMÓN, J. L. (2013). Weed management in cereals in semi-arid environments: a review. Andrew J. Price and Jessica A. Kelton, IntechOpen Book Series, 133-152. Doi:10.5772/55970.

SARANGI, D., JHALA, A. J. (2018). A statewide survey of stakeholders to assess the problem weeds and weed management practices in Nebraska. Weed Technology, 32, 5, 642-655.

SĂVULESCU et al., (1960). Flora RPR, Ed. Academiei RPR, Bucureşti, vol. VII, 505-565

SLONOVSCHI, V., LĂZĂRESCU, E. (2000). Prognoza răsăririi buruienilor din culturi de primăvară și cartarea buruienilor, două acțiuni absolut necesare utilizării raționale a erbicidelor. Simpozionul Național de Herbologie, Sinaia, 12, 45-53.

SLONOVSCHI, V., NITA, M., NECHITA, A. (2001). Prezent și viitor în combaterea buruienilor, Ed. Ion Ionescu de la Brad, Iași, 293.

TURK, M. A., TAWAHA, A. M. (2003). Weed control in cereals in Jordan. Crop Protection, 22, 2, 239-246. 